1975

\title{
Some Aspects of Late Prehistoric and Protohistoric Archaeology in Southern Texas
}

Thomas R. Hester

Center for Archaeological Research

T. C. Hill Jr.

Center for Archaeological Research

Follow this and additional works at: https://scholarworks.sfasu.edu/ita

Part of the American Material Culture Commons, Archaeological Anthropology Commons, Environmental Studies Commons, Other American Studies Commons, Other Arts and Humanities Commons, Other History of Art, Architecture, and Archaeology Commons, and the United States History Commons

Tell us how this article helped you.

This Article is brought to you for free and open access by the Center for Regional Heritage Research at SFA ScholarWorks. It has been accepted for inclusion in Index of Texas Archaeology: Open Access Gray Literature from the Lone Star State by an authorized editor of SFA ScholarWorks. For more information, please contact cdsscholarworks@sfasu.edu. 
Some Aspects of Late Prehistoric and Protohistoric Archaeology in Southern

Texas

Creative Commons License

(c) (1) (9)

This work is licensed under a Creative Commons Attribution-NonCommercial 4.0 International License 


\section{Some Aspects of \\ Late Prehistoric and Protohistoric Archaeology in Southern Texas}

THomas R. Hester and TE.Mil)

Center for Archaeological Research

The University of Texas at San Antonio

Speclal Report. No 1

1975

Second Printing 1977

UTSA - Center tor Archaeological Research 


\section{Center for Archaeological Research \\ The University of Texas at San Antonio}

78285

Thomas R. Hester, Director

Special Reports

Publications dealing with the archaeology of Texas and Mesoamerica.

No. 1 (1975) "Some Aspects of Late Prehistoric and Protohistoric Archaeology in Southern Texas" (By Thomas R. Hester and T. C. Hill, Jr.). (\$3.00+.15 tax for Texas residents). Second Printing, September 1977.

No. 2 (1976) "The Texas Archaic: A Symposium" (Edited by Thomas R. Hester). OUT OF PRINT

No. 3 (1976) "Papers on Paleo-Indian Archaeology in Texas: I" (Papers by T. R. Hester and W. W. Birmingham). $(\$ 3.00+.15$ tax for Texas residents).

No. 4 (1976)

"Maya Lithic Studies: Papers from the 1976 Belize Field Symposium" (Edited by Thomas R. Hester and Norman Hammond). ( $\$ 8.00+.40$ tax for Texas residents).

No. 5 (1977) "Hop Hill: Culture and Climatic Change in Central Texas" (By Joel Gunn and Royce Mahula). A limited number of copies are available for free distribution; however, please remit $\$ 1.90+.10$ tax to cover postage and handling. 
Center for Archaeological Research

The University of Texas at San Antonio

78285

Thomas R. Hester, Director

Special Reports

Publications dealing with the archaeology of Texas and Mesoamerica.

No. 1 (1975)

"Some Aspects of Late Prehistoric and Protohistoric Archaeology in Southern Texas" (By Thomas R. Hester and T. C. Hill, Jr.). $(\$ 3.00+.15$ tax for Texas residents). Second Printing, September 1977.

No. 2 (1976) "The Texas Archalc: A Symposium" (Edited by Thomas R. Hester). OUT OF PRINT

No. 3 (1976) "Papers on Paleo-Indian Archaeology in Texas: I" (Papers by T. R. Hester and W. W. Birmingham). $(\$ 3.00+.15$ tax for Texas residents).

No. 4 (1976) "Maya Lithic Studies: Papers from the 1976 Belize Field Symposium" (Edited by Thomas R. Hester and Norman Hammond). $(\$ 8.00+.40$ tax for Texas residents $)$.

No. 5 (1977) "Hop H111: Culture and Climatlc Change in Central Texas" (By Joel Gunn and Royce Mahula). A limited number of coples are avallable for free distribution; however, please remit $\$ 1.90+.10$ tax to cover postage and handling. 
SOME ASPECTS OF LATE PREHISTORIC AND

PROTOHISTORIC ARCHAEOLOGY IN SOUTHERN TEXAS

Thomas R. Hester and T. C. Hill, Jr.

Center for Archaeological Research

The University of Texas at San Antonio

Special Report, No. 1

1975

Second Printing 1977 


\section{SOME ASPECTS OF LATE PREHISTORIC AIND PROTOHISTORIC ARCHAEOLOGY IN SOUTHERN TEXAS}

Thomas R. Hester and T. C. Hill, Jr.

Center for ArchaeologicaI Research The University of Texas at San Antonio Special Report, No. 1

1975

Second Printing 1977 
Second Printing, September, 1977

with

Slight Revisions and Updated Bibliography 
TABLE OF CONTENTS

$\begin{array}{lc} & \text { Page } \\ \text { Introduction } & 1 \\ \text { Sites and Settlement Pattern } & 3 \\ \text { Internal Structure of Sites } & 7 \\ \text { Material Culture } & 8 \\ \text { Subsistence Remains } & 16 \\ \text { Pollen Analyses } & 18 \\ \text { Dating the Occupations } & 18 \\ \text { Summary and Discussion } & 20 \\ \text { Notes } & 24 \\ \text { Bibliography } & 30\end{array}$


LIST OF MAPS, FIGURES, AND TABLES

Maps

Page

1. Southern Texas and the Location of the Study Area

2. Locations of Late Prehistoric Sites in Zavaia and Dimmit Counties, Southern Texas

Figures

1. Lithic Artifacts of the Late Prehistoric Period

2. Lithic Artifacts of the Late Prehistoric Period

3. Ceramic Vessels from Southern Texas

Tables

1. Faunal Remains from Trash Pit ("Bone Pile"), Tortuga Flat Site (4I ZV 155)

2. Faunal Remains from Test Pits at Tortuga Flat (41 ZV 155)

3. Faunal Remains from Site $41 \mathrm{ZV} 60$

4. Faunal Remains from Holdsworth II

5. Fauna1 Remains from Test 4, 41 ZV 14 (1973) 


\section{INTRODUCTION}

This paper is concerned with the last several hundred years of the prehistoric period in the southern part of Texas. The earlier human occupation of this region, extending back perhaps 11,000 years, has been summarized elsewhere (Hester 1971a). The Paleo-Indian period is represented by scattered surface finds of Clovis and Folsom projectile points, and by a variety of "Late Paleo-Indian" point styles, such as Plainview, Scottsbluff, Golondrina, Angostura, and Meserve. The following Archaic era is poorly defined, although there are numerous surface sites and an abundance of chipped stone artifacts (cf. Weir 1956; Hester, White and White 1969).

The late prehistoric era in southern Texas shares many characteristics with contemporary cultural developments in other parts of Texas, during a period which Suhm, Krieger and Jelks (1954: 20) have termed "Neo-American". New traits which were introduced into some parts of Texas at this time include the bow and arrow, ceramics, and the practice of agriculture; present evidence indicates that of these, only agriculture was absent from southern Texas.

Because of a dearth of archaeological research in this part of the state, earlier syntheses (such as Suhm, Krieger and Jelks 1954) did not recognize distinct late prehistoric or "Neo-American" manifestations in the interior of southern Texas and adjacent northeastern Mexico. It was believed that the peoples of this area, ancestors of historic Coahuiltecan groups, survived in an Archaic-style, huniting and gathering lifeway until historic contact. There was some indication from surface sites (in the form of arrow points of the Perdiz, Scallorn and Fresno types) that the bow and arrow had been used in the area. However, there was no substantial evidence for the presence of ceramics, alterations in settlement patterns, different subsistence activities, or other modifications of the Iong-lived Archaic pattern.

Although there was a lack of cultural definition for the late prehistoric period in the interior of the Rio Grande Plain, research in the coastal area had led to the recognition of two archaeological complexes of this period. One is the Brownsville complex of the Rio Grande delta (Map 1). The material culture assemblage is dominated by artifacts of shell, evidencing a sophisticated shell-working technology (cf. MacNeish 1958). In addition, the Brownsville complex appears to have had extensive trade contacts extending down the northern Mexican coast and into the desert areas of northeastern Mexico. Another distinctive phenomenon was disposal of the dead in special cemetery sites (Hester 1969). However, very little is known about the settlement and subsistence aspects of this complex (cf. Prewitt 1974). A second cultural unit is the Rockport complex on the central and south-central Texas littoral, extending perhaps as far south as Baffin Bay (Map 1). Stemmed arrow points, sandy-paste 


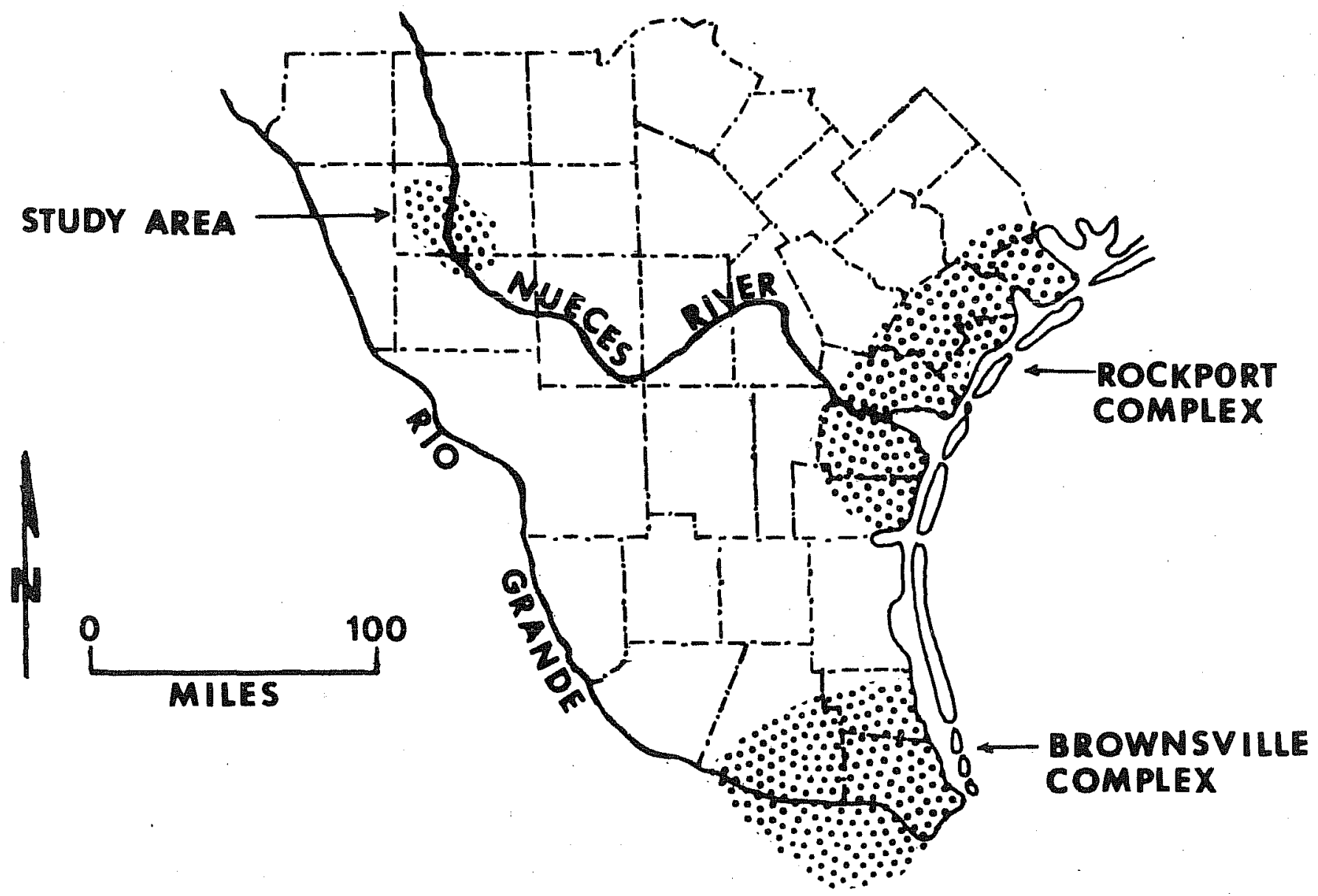

Map 1. Southern Texas and the Location of the Study Area. The areas encompassed by the Rockport and Brownsville Complexes are also indicated. 
ceramics (often with asphaltum decoration) and a core-blade technology are all traits of this complex (Campbell 1958; Corbin 1974; Hester and Shafer 1975).

Only in recent years have late prehistoric sites in the interior been systematically examined. One of the first results of the investigations was the recognition of a widespread ceramic tradition (Hester and Hill 1971). Bone-tempered plainware pottery has been reported from numerous surface sites scattered over the region. Surface evidence suggested that the tradition was prehistoric, at least in its origins, and affinities were noted with the bone-tempered Leon Plain ware of central Texas (Suhm, Krleger and Jelks 1954: 386-388).

Currently (1975) a variety of research is being done at late prehistoric sites on the Rio Grande Plain of southern Texas. This includes the work of the Chaparrosa Archaeological Project in Zavala County (University of Texas at San Antonio archaeological field courses were directed by the senior author at the ranch in 1974 and 1975), and various projects of The University of Texas at San Antonio, Center for Archaeological Research. One of the Center activities was the test excavation of the Hinojosa Site (41 JW 8), a late prehistoric site near Alice, Texas (Hester 1977). However, only in the northwestern part of the R1o Grande Plain, in the Zavala and Dimut Counties area (Map 2) have extensive excavations been carried out. These investigations include work mentioned above by Hester $(1970 ; 1974 \mathrm{~b})$ at Chaparrosa Ranch and an ongoing collaborative effort by the authors at sites on several stream drainages in Zavala County (Hester and Hill 1973; Hill and Hester 1973). Data have now been obtained on the cultural assemblage, settlement pattern, subsistence regime, and the temporal span of the late prehistoric peoples in this region.

\section{SITES AND SETTLEMENT PATTERN}

Archaeological materials excavated at several late prehistoric sites in Zavala County have now been analyzed. The major sites are described briefly below and are plotted in Map 2 .

1. $41 \mathrm{ZV} 14$ (Holdswonth I). Test excavations in 1970, published by Hester and Hill (1973); located on Tortugas Creek drainage east of Crystal City; Zone I at the site yielded abundant late prehistoric remains.

2. Holdsworth II. This is actually an excavation area in the southern part of $41 \mathrm{2V} 14$, excavated in 1973; large amounts of faunal materials in a thin midden deposit just below the surface.

3. Holdsworth III. Excavated in 1972, located just south of Holdsworth I-II, and adjacent to Tortugas Creek; upper part of midien deposit contains late prehistoric materials, while Archaic remains are found below. 
4. 41 ZV 155 (Tortuga Flat). Excavated in 1972-1973 (Hi11 and Hester 1973); a major late prehistoric and protohistoric site located approximately one mile downstream from the Holdsworth sites; rich midden deposit up to $9 \mathrm{~cm}$. thick; on east bank of Tortugas Creek.

5. 41 DM 70 (Spillway). Surface site on former channel of Nueces River, south of Crystal City; multi-component, with abundant late prehistoric Iithics and over 2000 potsherds; smaller potterybearing site is located on the same channel, just north of 41 DM 70 .

6. 41 DM 31, 41 DM 33. Surface sites on Former channel of Nueces River, south of DM 70; originally documented by Nunley and Hester (1966), but recent surface collections of lithics and ceramics from late prehistoric occupations have been made by Hill.

7. 41 ZV 11 (Chaparrosa 14). On west bank of Turkey Creek, northwestern Zavala County; excavated by Hester (1970); late prehistoric remains in upper $40 \mathrm{~cm}$.

8. 41 ZV 82 (Chaparrosa 27). On west bank of Turkey Creek, north of $41 \mathrm{ZV} \mathrm{11;} \mathrm{excavated} \mathrm{by} \mathrm{Hester} \mathrm{(1970);} \mathrm{the} \mathrm{upper} \mathrm{part} \mathrm{of} \mathrm{the}$ midden deposit contains late prehistoric materials.

9. 41 ZV 83 (Chaparrosa 28). On east bank of Turkey Creek; excavated by Hester in 1970 and 1974, and tested again in 1975 by the UTSA Archaeological Field Course; thick midden with upper levels radiocarbon-dated to late prehistoric and protohistoric times.

10. 41 ZV 10 (Chaparrosa 9). On east bank of Turkey Creek, downstream from $41 \mathrm{ZV} \mathrm{83;} \mathrm{excavated} \mathrm{by} \mathrm{Hester} \mathrm{in} \mathrm{1974.} \mathrm{The} \mathrm{upper}$ 15-20 cm. of the midden contains late prehistoric artifacts, small hearths, and faunal remains.

11. 41 ZV 123 (Jonnson \#1). Major late prehistoric midden on east bank of Chacon Creek; test excavations by Hill in 1971-1972; multi-component, with late prehistoric overlying deposits with Ensor and triangular dart points.

12. 41 ZV 60. Test excavations by Hill in 1971; late prehistoric midden deposits (up to $30 \mathrm{~cm}$. thick) on west side of $\mathrm{Palo}$ Blanco Creek.

13. Other major late prehistoric sites. All are surface sites: 41 DM 55 (Nueces River channel), 41 ZV 58 (Palo Blanco Creek), $41 \mathrm{ZV} 137$ (Nueces River channe1), $41 \mathrm{ZV} 157$ (east branch of Tortugas (reek). 
Map 2. Locations of Late Prehistoric Sites in Zavala and Dimmit Counties, Southern Texas. 


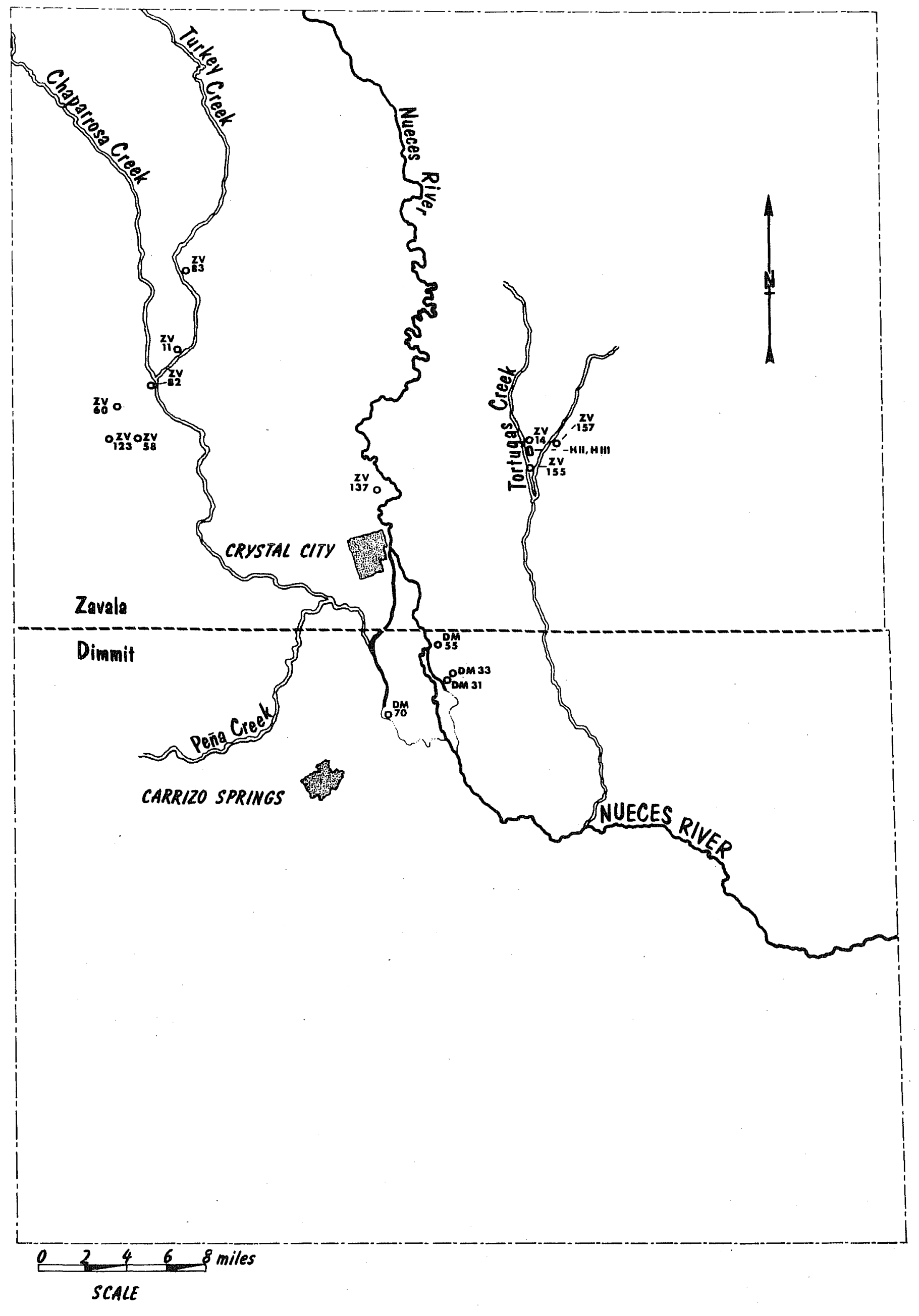


All of the presently documented late prehistoric sites are occupation loci, generally with concentrated midden deposits 10 to $30 \mathrm{~cm}$. thick. The middens yield large amounts of lithic debris, land snails

(Rabdotus sp.) ${ }^{3}$, lesser numbers of other snail species, mussel shells, scattered hearthstones of sandstone and chert, baked clay lumps, faunal materials and charcoal. In plan, these sites tend toward an oval shape, though they sometimes follow the linear pattern (paralleling a stream course) more characteristic of earlier (Archaic) occupations in the region. The buried middens are known to be up to 70 meters in length and 60 meters in width; however, the precise horizontal extent of most of these sites has yet to be ascertained.

Late prehistoric sites are concentrated in riparian microenvironments on the banks of large creeks (or the Nueces River and its former channels). Some sites of this period do occur in the floodplainriparian ecotone. The settlement distribution of the earlier Archaic and Paleo-Indian periods is inadequately known. Some late and middle Archaic materials underlie the late prehistoric remains in the riparian zone; other Archaic sites are found in mid-floodplain and on the bordering uplands. Early Archaic and Paleo-Indian artifacts are most commonly found at sites scattered along high terraces or upland fringes.

A centralized cluster of pottery-bearing late prehistoric (and probably protohistoric) sites is found along the middle Tortugas Creek drainage and on the Nueces River and its former channels; these two major drainage systems parallel each other in southern Zavala and northern Dimmit Counties. Intensive studies in western and northwestern Zavala County and western Dimmit County have produced only a few minor ceramic sites; interestingly, the abundant faunal remains which typify sites in eastern Zavala County are also absent in these western sites.

\section{INTERNAL STRUCTURE OF SITES}

Most excavations to date have been of the sondage (test pit) variety, and we thus have little information on the spatial patterning of the late prehistoric campsites. Data from "horizontal" excavations conducted at $41 \mathrm{ZV} 83$ (Chaparrosa 28) in 1974 have not yet been fully analyzed. However, at this site and especially at $41 \mathrm{ZV} \mathrm{10}$, hearth areas, pits filled with charcoal, ash and baked clay, and areas of concentrated lithic refuse, have been exposed. At site $41 \mathrm{ZV} \mathrm{155,} \mathrm{a}$ probable trash pit (perhaps an erosional cut into which debris was thrown) was found. It contained a large quantity of animal bones (thus the field designation, "Bone Pile"), bits of lithic debris, baked clay lumps, and two discarded arrow points. Sheet erosion in another part of the same site revealed hearths in place, and around these, potsherds were clustered. Test 4 at $41 \mathrm{ZV} 155$ produced most of the crude bifaces or preforms at this site. Analysis of debitage from that unit revealed a high incidence of biface thinning flakes (flakes diagnostic of bifacial reduction), approximately $55 \%$ of the identifiable flakes (prinary cortex, secondary cortex and interior flakes being the other major types). 
At $41 \mathrm{ZV} 14$ (Holdsworth I), an ash-stained area dating to late prehistoric or protohistoric times was excavated. Found within this area were charred limbs, sticks and other woody remains; it is remotely possible that this represents a partially-burned brush hut structure (for alternative explanations, see Hester and Hill 1973). A probable "late Archaic" living floor was found at the same site.

Late prehistoric and protohistoric sites in the Turkey and Chaparrosa Creek drainages contain hearths (oval arrangements of fire-cracked cobbles), clusters of land snails, mussel shell concentrations, and, at $41 \mathrm{ZV} 82$, a pit filled with ash and baked clay fragments, probably related to cooking activities.

\section{MATERIAL CULTURE}

Prior to 1970, surface collections from late sites on the Rio Grande Plain of southern Texas had yielded arrow points ( primarily of the Perdiz, Scallorn and Fresno types; see Suhm, Krieger and Jelks 1954), some bone tempered ceramics, and tools made on small flakes. Surface associations at some sites, particularly $41 \mathrm{ZV} 34$ (Honeymoon), led to the formation of a hypothesis that small, thick "dart points" were coeval with arrow point forms and were part of the late prehistoric cultural inventory (Hill and Hester 1971).

Excavations at the previously described sites have confirmed these earlier assumptions, but more importantly, they have provided us with a much greater knowledge of the content of the late prehistoric cultural assemblage.

Lithic Artifacts

Arrow points (Figure 1, a-o, Figure 2, a-h). The dominant projectile point form from excavated contexts is the stemmed Perdiz type. Stemmed points reminiscent of Scallorn and Edwards also occur, as do triangular points similar to the Fresno type, triangular points with convex bases, and lozenge-shaped specimens. At $41 \mathrm{ZV} 155$ (Tortuga Flat) and certain other late sites such as $41 \mathrm{ZV} 83$, all of these point styles co-occur in thin midden deposits and would thus seem to be contemporary. Also included in the arrow point series are small side notched points (similar to Ensor; see Figure 2 , e, f), and a thick, stubby form tentatively termed Zavala, both of which technologically resemble miniature dart points. At some sites, points similar to the Cliffton type occur (Figure 2, g), although these are more likely unfinished Perdiz specimens. Two points which are typologically Cuney (a form primarily restricted to eastern Texas; Suhn, Krieger and Jelks 1954: 498) were collected from the surface of site 41 DM 33 (Nunley and Hester 1966). 
Other bifacial tools (Figure 1, r; Figure 2, k). Most common are crude ovate to triangular bifaces, either preforms or knives. Bifacial drills or perforators occur; some of these are made on thin flakes, but one completelybifaced "T-shaped" specimen is known from Holdsworth II deposits. At Tortuga Flat ( $41 \mathrm{ZV}$ 155), a fragmentary four-edge beveled knife was found (Figure 1, r).

Unifacial tools (Figure 1, p, q, s; Figure 2, i, j). End scrapers are repeatedly found and consist of two major forms: (1) those made on thin, light flakes or flake blades; (2) specimens made on large, thick cortex flakes. There are also unifaces made on long flakes, with a scraping or cutting edge oriented obliquely to the bulb of percussion ("oblique scrapers"). Laterally-trimmed flakes ("side scrapers") are found. A large unifacial implement was associated with a concentration of faunal remains (the "Bone Pile") at 41 ZV 155. It exhibits evidence of very heavy use along the working edge and may have been used as a chopper for butchering tasks.

Lithic technology. Debitage analysis has been done for only a few late prehistoric sites (Hill and Hester 1971; Hester and Hill 1973; Hester 1975). Both percussion and pressure techniques are represented, and in general, flakes are smaller than those in the earlier lithic industries in the region. Flakes were used for the manufacture of arrow points, scrapers, perforators, and casual cutting tools ("utilized flakes"). Sometimes, only minimal edge trimming was required to shape a suitable arrow point. There are also indications of the existence of a blade technology. A number of blades and exhausted polyhedral blade cores have been found. Small blades were used for making Perdiz and other arrow point forms, and the larger blades, for end scraper manufacture.

Artifacts of Ground, Pecked and Polished Stone.

Seed-grinding implements are rare; no milling slabs are reported and manos (usually of limestone or sandstone) are infrequent. Hammerstones are quite common, and are invariably made on small cobbles of purple quartzite (a preferred material among the area's prehistoric flint knappers; Hester 1975). A deeply engraved sandstone pipe, roughly tubular in shape, was recovered during excavations in Test 4 at $41 \mathrm{ZV} 14$. From the surface at the same locality came a rim fragment of a micaceous schist vessel or bowl.

Several late sites have yielded (from surface contexts) loafshaped limestone cobbles which have a single transverse groove and several longitudinal scratches or lightly-engraved lines (cf. Hill, House and Hester 1972). These objects are similar to arrow shaft straighteners found in late prehistoric and early historic California Indian sites, as well as in the 
Figure 1. Lithic Artifacts of the Late Prehistoric Period. a-o, arrow points; p, q,s, unifacial tools; r, beveled knife. All specimens from $4 I \mathrm{ZV} 155$ (Tortuga Flat). 
政
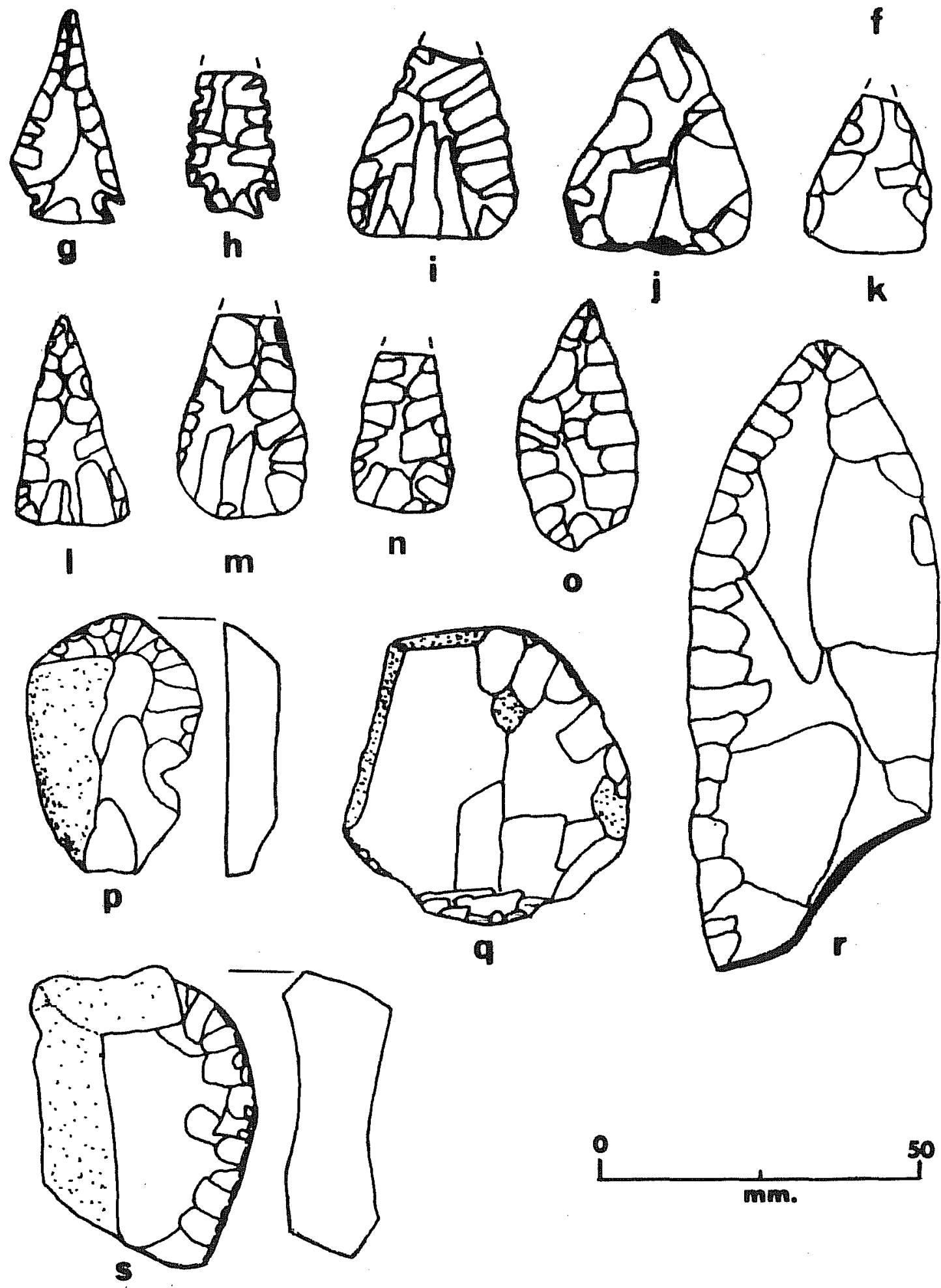
Figure 2. Lithic Artifacts of the Late Prehistoric Period. $a-\mathrm{h}$, arrow points; $i, j$, unifacial tools; $k$, biface. All specimens from the Holdsworth II site, Zavala County. 

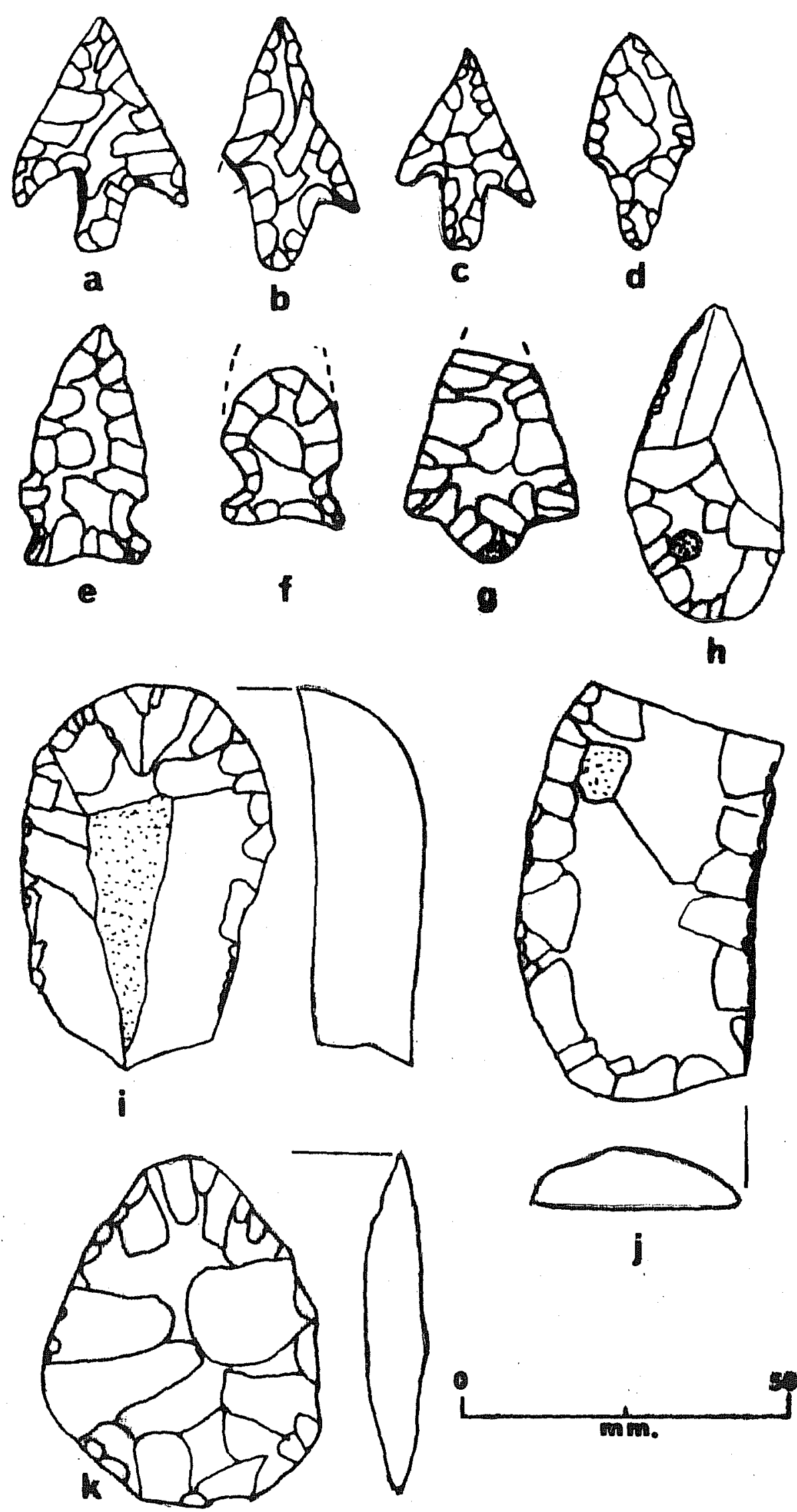
American Southwest (Kroeber 1925; Walker 1933; Kelley 1948). It is postulated that these artifacts were introduced along with the bow and arrow in southern Texas.

Artifacts of Bone and Antler.

Bone and antler artifacts are relatively rare. They consist largely of small tubular bone beads made from sections of bird or mammal long bones (for illustrations of these, see Hester, Hill, Gifford and Holbrook 1975). Bone implements include pressure-flaking tools made of deer ulna or antler tine, and highly polished bone awls. Some of the latter may have conceivably functioned in basket-making (cf. Kroeber 1925).

\section{Ceramics}

Bone-tempered plainware pottery (Hester and Hill 1971) has been found at many late prehistoric sites in southern Texas, particularly along the middle Nueces River drainage. The pottery was originally reported from surface contexts, but numerous potsherds have subsequently been excavated at sites along Tortugas Creek.

Vessels were formed by the coiling technique and fired in an oxidizing atmosphere. Exterior surface colors are predominately red, yellow, pink and gray. Decoration of exterior surfaces (incised lines, painted red bands) has been noted but is very rare. In general, exterior surfaces are well-smoothed and burnished and are quite hard (usually 3.0 - 4.0 on Moh's scale). Interiors are poorly finished and the coil junctures can often be seen. The interiors are sometimes striated, and this has been interpreted as resulting from the use of a bundle of grass or a stick in smoothing.

Experiments by Hill (1975) indicate that smoothing with the fingers can also cause such striations, as tiny sand grains and other particles are picked up and dragged across the surface during the smoothing process.

Some sherds appear to have a red slip on the exterior surface. The paste is usually quite compact and contains finely-crushed bone-tempering agents. Vessel shapes are poorly known. Two ollas (Figure 3) have been recorded from a site in Karnes County (Calhoun 1966), but in other parts of southern Texas, vessels were apparently small round-bottomed bowls or jars, although one flat-bottomed vessel has been observed in a private collection in Dimmit County. Attachments on the vessels consist of loop handles and lugs.

In general, southern Texas ceramics compare closely with the Leon Plain tradition of late prehistoric central Texas, and with the bone-tempered ceramics found along the southwestern 


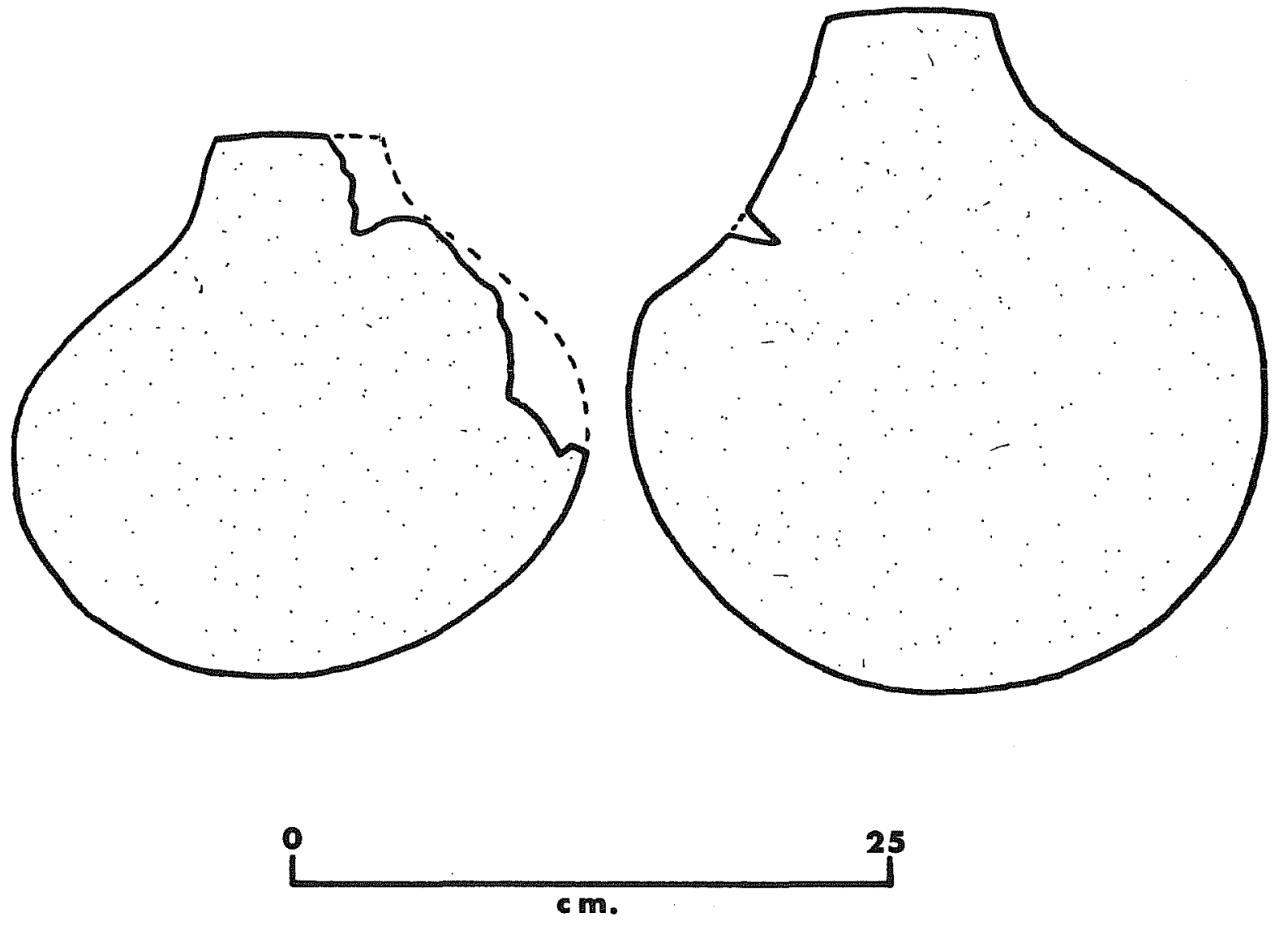

Figure 3. Ceramic Vessels from Southern Texas. 011as from site $41 \mathrm{KA} 1$ (Scarborough Farm site, Karnes County, Texas; after Calhoun 1966). 
edge of the Edwards Plateau (Hester 1971b). Intensive experiments designed to replicate the bone-tempered ceramics of southern Texas, using crushed bone and local clays, have been published by Hill (1975).

In addition to the predominant bone-tempered tradition, some sandy-paste sherds similar to the coastal Rockport ware are known from the interior of southern Texas (especially at site 41 DM 70). A grog-tempered jar was found at the Berclair site in Goliad County (Hester and Parker 1970).

\section{SUBSISTENCE REMAINS}

Our data on late prehistoric dietary patterns comes largely from the analysis of animal bone refuse found at several excavated sites. The only direct evidance of plant foods is in the form of two charred acorn fragments from Holdsworth III and the occurrence of charred spiny hackberry (granjeno) seeds at $41 \mathrm{ZV} 10$.

We believe that the bulk of the large numbers of land snails (Rabdotus sp., particularly R. schiedeanus) found at late sites in the region represent intentionally-gathered food items. Support of this belief may be derived from the occurrence of clusters of snails at some sites. According to Krieger (1956: 53), snails were a major food source during sumer months for aboriginal peoples on the central Texas coast (for further comments on the occurrence of snails in Texas archaeological sites; see Suhm 1957, Clark 1973). Experiments carried out by Hill have shown that the slug may be easily extracted from the snail shell after having been placed in boiling water for a very few minutes (Hester and Hill 1975). The clusters of adult snails revealed in the excavation of late sites may represent the results of snailcollecting forays, or may indicate areas of a site in which extraction of the meat (or slug), perhaps via the boiling process, was carried out.

Mussels (Unio sp.) are also found in the late middens. These probably also served as a food resource (as well as a raw material for ornament manufacture), and could be collected from the streambeds adjacent to the sites.

Faunal remains from several Zavala County sites were identified by Paul Hayward (formerly of the University of California, Berkeley) and Billy Davidson (Laboratory of Vertebrate Paleontology, University of Texas at Austin). These analyses were funded by an American Philosophical Society grant to the author (see Hester 1974a). Additional faunal studies by Davidson, utilizing materials from the 1975 excavation at $4 \mathrm{IV} \mathrm{10,} \mathrm{were} \mathrm{underway} \mathrm{at} \mathrm{the} \mathrm{time} \mathrm{this} \mathrm{manuscript} \mathrm{was} \mathrm{being}$ prepared.

The outstanding feature of the faunal collection is the wide range of species represented. At site $41 \mathrm{ZV} 155$, a probable trash pit ("Bone Pile") contained the remains of twenty-two different species of mamals 
and reptiles. The total number of individual species found at $41 \mathrm{ZV} 155$ (in the "Bone Pile" and the several test pits) comes to twenty-six. At the nearby Holdsworth II locality, twenty-one species were identified. Faunal remains from several Zavala County sites are listed in Tables $1-5$.

The faunal data provided information both on subsistence and on environmental change. In regard to subsistence, it is apparent that many kinds of animal foods were used. Antelope and deer constituted the major large game, while bison was only rarely obtained. It is possible that the major meat sources were the sma11 mammals - the rabbits and rodents (cf. Hester, Hill, Gifford and Holbrook 1975). Reptiles such as turtles (especially Terrapene sp.), snakes, frogs and fish were also utilized. Coyote, gray fox, raccoon and some other manmals may have been killed for their skins or pelts rather than for food. Birds were a minor element in the diet, and of these, wild turkey was probably the most important.

A perusal of the faunal tabulations reveals no recognizable predilection for any particular microenvironments for the hunting (or gathering) of animals. The bison and antelope were probably more common in upland situations. Deer and many of the small mammals inhabited a variety of. closely-spaced microenvironments. The riparian microenvironment, if thickly wooded (with dense underbrush) as today, would have attracted rabbits and rodents. The streams provided fish, frog, slider turtle, and possibly duck. In general, most of the fauna represented in these sites could have been obtained by late prehistoric hunters and foragers in the immediate site area or without venturing far from their streamside camps.

There are two mammalian species in the faunal assemblage which are no longer present in the area. In addition, two species now common in southern Texas and northeastern Mexico, the peccary (javelina) and the armadillo, are not found. Both are regarded as relatively late intruders. Those species now absent from southern Texas are bison and antelope. Data gleaned from the reports of early Spanish and Anglo. visitors to the region indicate that large bison herds rarely ventured into the area, although Manzanet observed considerable numbers of the animals in northern Zavala County in 1691 (Inglis 1964). Antelope were widespread in southern Texas well into the nineteenth century (ibid.).

The bison and antelope can be taken as indicators of environmental change. Both are at home in rather open savanna or steppe vegetation; antelope is particularly characteristic of short-grass prairies (cf. Gilbert 1973). Their presence in late prehistoric contexts offers support for the hypothesis advanced by wildiffe ecologists and range specialists that the mesquite brushland environment in southern Texas has come about only during the past 200-300 years (Price and Gunter 1943; Inglis 1964). This, of course, does not mean that the area was a vast prairie grassland; rather, documentary evidence suggests thick vegetation along the streams (and in the uplands in some areas), but with more open, grassy uplands 
than found in the region today. Arong the aboriginal practices which may have sustained the grassland pattern was the recurrent burning of the prairies (cf. Covey 1961; Reeves 1973).

There is always the possibility that some of the fauna in the late prehistoric middens were introduced through a variety of natural agencies (packrat nests, carnivore kills, burrowing animals, to name a few). However, the charred and comminuted nature of most of the remains strongly suggests that man was the primary agent in their deposition in the middens.

\section{POLLEN ANALYSES}

In an effort to obtain further information on prehistoric environments, particularly the late period, soil samples from Chaparrosa Ranch sites were analyzed for pollen content (Hester 1974a) ${ }^{4}$. The analyses revealed that all samples were almost totally void of pollen. Fungal spores were present in the samples, suggesting that fungal attack could have destroyed any pollen grains once present. Alternatively, severe oxidation and high alkalinity, both characteristic of the Chaparrosa soil samples, could have eliminated any fossil pollen. Pollen samples from Tortugas Creek sites have not yet been submitted for study.

\section{DATING THE OCCUPATIONS}

Initial studies of the late prehistoric era in southern Texas rere made with the working assumption that the lithic materials could be correlated with the cultural sequence in adjacent central Texas. Thus, Perdiz, Scallorn and other diagnostic arrow point types collected from surface sites in the region were cross-dated in relation to the established temporal niche of the particular type in central Texas. In the central Texas chronological framework, there is the Austin phase (or "focus") beginning around A.D. 500, and typified by the presence of Scallorn arrow points. About A.D. 1200 the Toyah phase (see a recent definition by Shafer 1971) commences, with diagostic artifacts including Perdiz arrow points, Leon Plain bone-tempered ceramics, lozenge-shaped beveled knives and certain other Iithic forms. Based on present data from excavated Zavala County sites, it would appear that this cultural dichotomy was not present on the Rio Grande Plain. At site $41 \mathrm{ZV}$ 155, both Scallorn and Perdiz (as well as other arrow point styles) occur in a common context, and these associations have been confirmed at other sites. Moreover, small, thick projectile points of side-notched and rectangular-stemed forms (Zavala points), are contemporary with the more typical arrow point styles. All of these data show that several kinds of arrow points were used at the same time, and make it obvious that we cannot use cross-dating (through the use of convenient horizon-marker projectile point types) as a mechanism for determining the age of the late occupations. 
Presently, we have a suite of radiocarbon dates, based on charcoal samples from five late prehistoric/protohistoric sites. From the final aboriginal occupation at Holdsworth I (4I ZV 14; Hester and Hil1 1973), we have a radiocarbon assay of "not greater than 300 years", or roughly A.D. 1650 (UCLA-1821A). At $41 \mathrm{ZV} 155$ (Tortuga Flat), just downstream, two radiocarbon dates are available. One is A.D. 1780 ( $\mathrm{Tx}-1514)$, and the other, A.D. 1540 ( $\mathrm{Tx}-1515$; Hill and Hester 1973). However, it is necessary to adjust these dates to conform with recent refinements in calculating radiocarbon age. Through the combined use of dendrochronology and radiocarbon dating with certain long-lived trees, particularly the bristlecone pine and sequoia, it has become evident that adjustments are required of many radiocarbon determinations. We have used the adjustments, or calibrations, recently published by Ralph, Michael, and Han (1971). For example, the date of ca. A.D. 1650 at Holdsworth I actually falls in the A.D. 1610-1520 range, the A.D. 1780 date at $41 \mathrm{ZV} 155$ is corrected to A.D. 1760-1660, and the A.D. 1540 date must be pushed back to A.D. 1440. With these corrections, the dates for the late occupations along the Tortugas Creek drainage fall between A.D. 1440 and A.D. 1760, spanning the late prehistoric and early historic eras. In another paper (Hill and Hester 1973), we have described the occupations at $41 \mathrm{ZV} 155$ (Tortuga Flat) as "protohistoric". This term was employed since the occupations apparently extend into historic times (on the basis of radiocarbon determinations), yet there is no recognizable archaeological evidence of any contact with Europeans.

Radiocarbon determinations are also available for sites on Chaparrosa Ranch in northwestern Zavala County. At site $41 \mathrm{ZV} 83$ (Chaparrosa 28), a date of A.D. 1520 (corrected to A.D. 1430; Tx-1526) was obtained from level 2. Levels 1 and 2 at this site contained triangular arrow points with convex bases, a Scallorn arrow point, and a thick, side-notched point. Level 3 at the site was dated to ca. A.D. 1650 (UCLA-1821D), and leve1 4, A.D. 550 (UCLA-1821E; corrected to A.D. 620).

Another radiocarbon date is from $41 \mathrm{ZV} 82$ (Chaparrosa 27) and is A.D. 1450 (corrected to A.D. 1410). This assay ( $\mathrm{Tx}-1527$ ) represents an occupation prior to the final aboriginal habitation which left behind triangular and Zavala arrow points.

At $41 \mathrm{ZV} 11$ (Chaparrosa 14), a date of ca. A.D. 1650 (UCLA-1821B) was obtained for the final occupation (level 1), containing a small side-notched arrow point. Level 2 at this site $(20-40 \mathrm{~cm}$. below the surface) has two radiocarbon dates, A.D. 415 (UCLA-1821C; corrected to A.D. 490-510) and A.D. 770 ( $\mathrm{Tx}-1525$; corrected to A.D. 850-830). These dates suggest an Archaic occupation; unfortunately, no diagnostic artifacts were recovered. 
SUMMARY AND DISCUSSION

In this paper, we have examined the archaeological remains of late prehistoric peoples in southern Texas, focussing attention on excavated materials from the northwestern sector of this region. We are beginning to recognize intra-regional variation within the late prehistoric era in this part of Texas. For example, there are the Brownsville and Rockport complexes, defined largely as coastal manifestations. We have, on the other hand, described a series of rich late prehistoric and protohistoric middens located along the middle Tortugas Creek drainage and the parallel Nueces River system. These sites appear to contrast significantly with other late sites in the interior of southern Texas, particularly the sites excavated from 1970 to 1975 on the Chaparrosa Ranch of northwestern Zavala County. If one further compares the Tortugas Creek components (particularly their artifactual inventories) with late sites to the south in the Falcon reservoir area along the lower Rio Grande (Suhm, Krieger and Jelks 1954), or, as another example, to the southeast in Duval County (Hester 1972c), even greater differences are noted. However, it must be emphasized that many of these contrasts, which seem so obvious at the present time, may simply reflect the lack of intensive survey and sampling in some sections of southern Texas.

Let us summarize the data presented here relating to the late prehistoric occupation in the northwestern Rio Grande Plain. In doing this, we can present a general description of the lifeway of these late populations.

The settlements or occupation loci of the late period were situated in riparian environs along major stream courses. There were shortterm hunting and foraging camps in other environmental locales, especially in the uplands, but these have not yet been carefully studied in terms of their distribution (one temporary site documented by Hill and Hester 1971, was situated in a floodplain locale). Daily activities and functions seem to have taken place in a rather limited area, and compact, refuse-filled middens have resulted. It is difficult to ascertain the criteria used by these peoples to select camping locations; availability of water was obviously one consideration, but more important factors may have been animal and plant resources in the site vicinity, especially seasonally available plant foods (cf. Ruecking 1953; Hill and Holdsworth 1973). From the faunal lists given in Tables $1-5$, it is obvious that many of the species would have been at home in the riparian zone (or at least nearby). However, other productive microenvironments (floodplain, upland slopes, uplands) were easily accessible and the importance of the riparian strip should not be given undue emphasis.

We still have relatively few data on intrasite patterning, although excavations in 1974 and 1975 have provided evidence of several forms of activity or structural 1oci. We need additional broad, horizontal exposures of sites. The excavations conducted thus far suggest that many of the sites are, in reality, "occupational zones", with numerous often overlapping, discrete occupational episodes having occurred. 
We have not made any serious attempt to estimate the size of the population represented by the late prehistoric or protohistoric sites under investigation. Site size is sometimes considered as a basis for making population guesses. However, Cook (1972: 19) has warned that other criteria in addition to site size, such as the number of structures per site (cf. Narol1 1962), must be taken into consideration. In our particular case, the data on site size are inadequate, as most of these sites are buried; we suspect that an average dimension of ca. $3600 \mathrm{~m}^{2}$ may be realistic.

The whole situation regarding population size is complicated by the fact that there are numerous and widely divergent population figures given for the "Coahuiltecan" peoples of southern Texas and northeastern Mexico (Ruecking 1955). We do, however, wish to call attention to a study by Weddle (1968) in which Spanish encounters with Indian groups in the Dimmit and Zavala Counties area are related. These reports derive specifically from an expedition of March, 1707, from the Presidio San Juan Bautista, on the south side of the Rio Grande in Coahuila. Near present Big Wells in Dimnit County, the Spaniards found a camp of the Pacque (Coahuiltecan), composed of 21 men, women and children. At a campsite in nearby Webb County, the expedition came upon an abandoned Indian village with "15 huts of mare's skins" (Weddle 1968: 83). Also in Webb County (or possibly LaSalle County) they attacked two villages, and 30 Indians were killed or captured; only two escaped, one of these being an "old woman who had just left to hunt rats" (Ibid.: 82). On the return trip to San Juan Bautista, the expedition encountered, probably in southwestern Dimmit County, "four rancherias of the Pacuq (sic) and Puyvas nations (note: these are both Coahuiltecan groups) composed of 21 persons" (p. 85). Although it is not made clear, we suspect that the Spanish account intended to state that there were ca. 21 occupants at each of the four rancherias.

The limited data cited above, provided by an early 18 th century Spanish expedition, would suggest that the number of people occupying a particular campsite was rather small, usually less than 30 persons. It is hoped that additional ethnohistoric research will shed new light on this problem. Recent studies by $T$. N. Campbell (University of Texas at Austin) have led him to believe that these groups were often substantially larger, approaching 100 persons (personal communication, 1975).

Although we are convinced that the archaeological evidence indicates that we are dealing with fairly small groups of people (as described in the ethnohistoric record) there are no direct data which would also allow us to make inferences regarding their social organization. Future excavations may provide some clues in this regard, but we doubt that this problem can ever be satisfactorily resolved. A major complicating factor is, again, the ethnohistoric record for the area. Ruecking (1953, 1955) believes the southern Texas aboriginal population to have been organized as "bands". Newcomb (1961) describes them as "small family groups" which coalesced during seasonal plant food harvests. Most recently, Nunley (1971) has proposed the term 
"dialectic tribe" in discussing the possible social organization of Archaic populations in Webb and Zapata Counties.

We now have substantial archaeological data on the late prehistoric tool kit. The principal weapon and hunting device was the bow and arrow, the arrow tipped with small flint points of various shapes. Tools required for making components of the bow and arrow unit included quartzite hammerstones and bone pressure-flaking tools, and a grooved loafshaped stone used to straighten arrow shafts. Other manufacturing and/or processing implements include bifaces (some of which must have served as knives), scrapers (for working hides, for fibre preparation, wood-working, and so forth), perforators of chipped stone, pointed bone tools used either as awls or as basketmaking aids, and manos or rubbing stones. Containers for storage or cooking included bone-tempered bowls or jars and perhaps stone vessels. Ornaments are rare, primarily small tubular bone beads. The stone pipe at one site may have conceivably been used in rituals or ceremonies, or perhaps simply as a smoking pipe.

Regarding the subsistence regime, we can state unequivocally that a wide spectrum of fauna was exploited, including both terrestrial and aquatic species. There may have been an emphasis on small mammals, particularly rabbits and rodents (the Spanish account cited earlier suggests that the latter were caught by old women), but the fiew large mammals represented in the faunal collections (bison, antelope, deer) would have contributed a great deal of meat during a short-term occupation of a site. We have extremely meager archaeological data on plant food use, yet we know from ethnohistoric accounts (cf. Ruecking 1953) that these resources probably figured heavily in the diet (the abundant plant foods available in the Tortugas Creek drainage have been documented by Holdsworth 1973; Hi11 and Holdsworth 1973). We do not know how the late prehistoric subsistence endeavors were structured. Was it a cyclical (seasonal) subsistence pattern? This would seem a reasonable inference based on a perusal of the ethnohistoric record. Certainly, the smallness of the sites and the large numbers of campsites scattered along the streams indicate a pattern of continuing movement. The archaeological and ethnohistorical data combined suggest that these peoples were "restricted wanderers", operating within an owned territory (Ruecking 1953; Nunley 1971; Chang 1972). When finances permit further and more detailed analysis of the faunal materials, especially of the ages of the various animals represented, we might obtain important clues as to the times of the year during which the Tortugas Creek sites were inhabited. According to Ruecking (1953: 498), the occurrence of bison at these sites might indicate a winter-early spring occupation.

There are also data, although not directly from the excavated sites, on two other important facets of late prehistoric life. Mortuary practices have received some attention (Hester 1969). Along the coast, interment in discrete cemetery areas may have been the burial mode during this period. In the interior, burials have rarely been found, but when they occur, they are often away from the camping areas (although some have been found in midden deposits). The form 
of disposal included flexed and extended inhumations and cremation. Burial goods are sparse (cf. Hester, Hill, Gifford and Holbrook 1975). Systems of exchange or trade were also a part of late prehistoric culture. Ethnohistoric accounts (particularly that of Cabeza de Vaca) relate the occurrence of trade in early historic times, and this is supported by archaeological evidence for the late prehistoric era. In the Brownsville complex, there are artifacts of jade and obsidian, elaborately-carved conch shell ornaments, and Huastecan vessels. These materials are coming out of Mexico, perhaps largely via the Huasteca. The shell industry of Brownsville times may have figured as one medium of exchange in dealing with Mexican groups. In the interior, there is a wide assortment of exotic artifacts, many of which are not fixed temporally. In the late prehistoric period, there seem to be exchange or trade vectors pointing toward Mexico (obsidian, spindle whorls, and other objects), west Texas and New Mexico (ceramics, obsidian), and the Texas coast (shell tools, ornaments and Rockport Black-cn-Gray ceramics). 5

We do not think there are sufficient data to elaborate on the subject of tribal or linguistic affiliation of the late prehistoric peoples (for a brief review, see Hill and Hester 1973). It is most likely that they were "Coahuiltecan" speakers (there were certainly "Coahuiltecan" groups in the study area at the time of historic contact), although on the northern fringes of southern Texas there may well have been occupation by "central Texas" (i.e., Toyah phase) peoples. Regarding the latter, it is interesting to note the similarities between the sites and materials of the Tortugas Creek drainage and the Toyah phase (Shafer 1971), an archaeological manifestation tentatively linked to the historic Tonkawa (Suhm 1958).

In conclusion, our knowledge of the late prehistoric occupation of parts of southern Texas has greatly increased in the past few years. However, as this discussion has indicated, there are major gaps yet to be filled. Many areas of southem Texas remain unknown and relationships between these and the better-known portions are clouded. With expansion of a program of problem-oriented excavation and site survey, and the intensification of ethnohistoric research, we suspect that new and significant data on the peoples of southarn Texas will be forthcoming. 
NOTES

1 Research reported in this paper was supported in part by a grant to Hester from the Penrose Fund (\#6313) of the American Philosophical Society in 1972. An earlier version of the paper was presented at the Second Borderlands Conference in San Antonio, Texas, October 19, 1973.

2 The term "Rio Grande Plain" is often used by range specialists to refer to southern Texas, an area of 38 million acres lying south of the Balcones Escarpment and southwest of the Guadalupe River (Inglis 1964: 1).

3 At some sites (such as $41 \mathrm{ZV}$ 123), Rabdotus sp. snails which are much larger than those commonly observed today have been found, and these often occur in clusters.

4. Pollen analyses were done by Dr. Vaughn Bryant, Jr. of Texas AâM University, and were funded by Chaparrosa Ranch, La Pryor, Texas (B. K. Johnson, owner; Wayne Hamilton, ranch resources manager).

5 Published data on trade in prehistoric southem Texas may be found in Hester (197lc, 1972a, 1972b); Hester and Hi11 (1969); and Hester, House, Jack and Stross (1975). 
TABLE 1.

Faunal Remains from Trash Pit ("Bone Pile"),

Tortuga Flat Site (4I 2V 155)

Scientific Name

Bison sp.

Antilocapra americanus

(Antilocaprid)

odocoileus virginiana

Canis latrans

Lepus californicus

Sylvilagus floridanus

(and Sylvilagus sp.)

Sciurus niger

Geomys bursarius

Geomys sp.

Neotoma microps

Sigmodon hispidus

Peromyscus sp.

Procyon lotar

Urocyon cinereoargenteus

Terrapene sp.

Pituophis melanoleucus

Elaphe sp.

Fish

Bird

Bird

Lagomorphs

Artiodactyls

Turtle
Common Name

bison

antelope

cf. antelope

whitetail deer

coyote

jackrabbit

cottontail rabbit

fox squirrel

pocket gopher

gopher

packrat

cotton rat

white footed mouse

raccoon

gray fox

box turtle

bullsnake

ratsnake

sp. ?

cf. mockingbird

cf. ducle

rabbits

deer, antelope

sp. ?
No. Individuals

1

3

2

9

2

3

1

2

1

6

13

1

I

1

2

1

1

5 ?

1

1

2

several

1 
TABLE 2 .

Faunal Remains from Test Pits at Tortuga Flat (41 ZV 155)

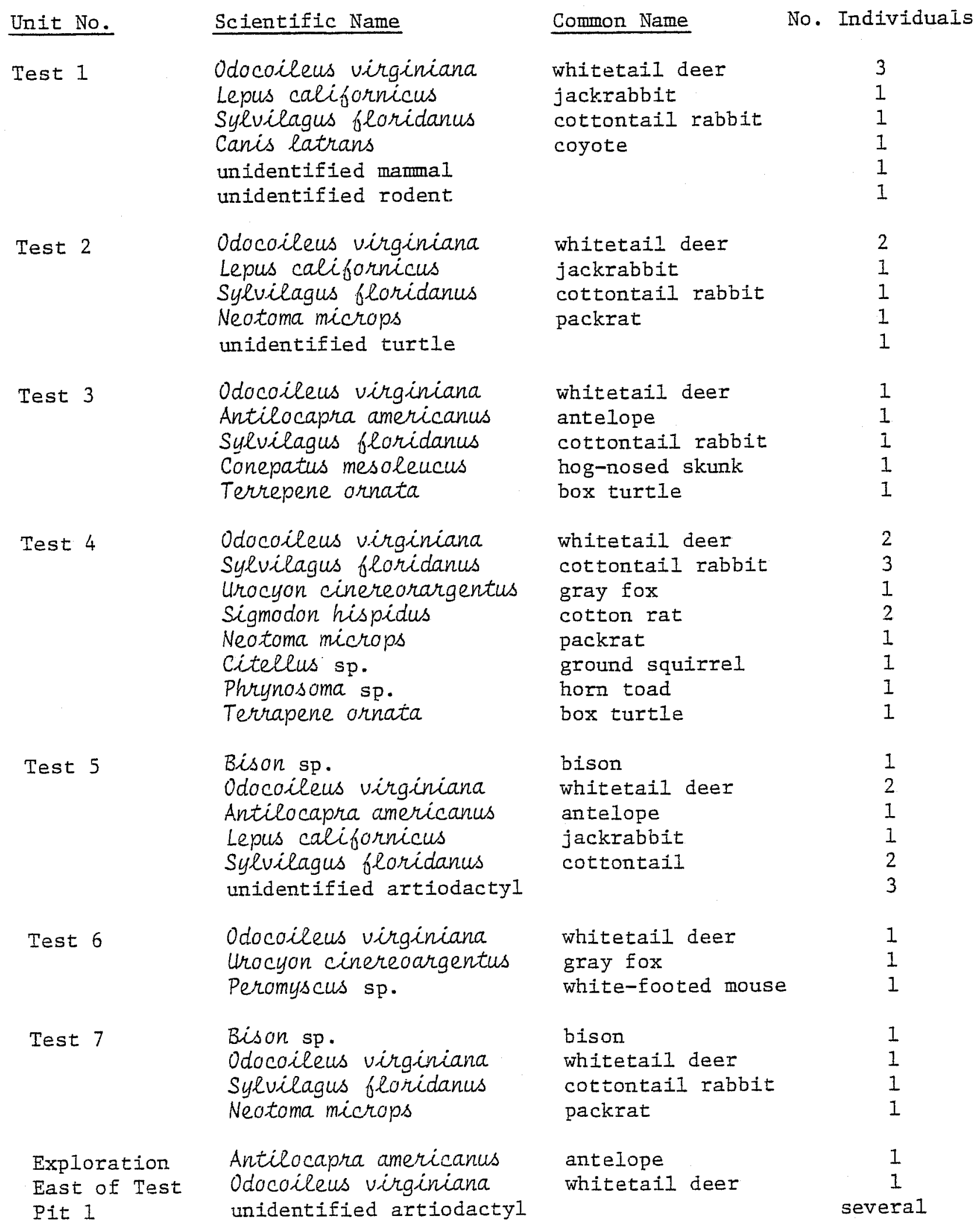


TABLE 3.

Faunal Remains from Site 41 ZV 60

Scientific Name

Common Name

No. Individua1s

Surface

hearths

Odocoileus virginiana

Canis latrans

whitetail deer

coyote

Sylvilagus floridanus

Lepus californicus

Neotoma microps

cottontail rabbit

jackrabbit

packrat

Unidentified

artiodactyls

unidentified bird

deer?

1

1

1

1

2

$?$

1

Test 1

Leve1 1 Lepus californicus

Sylvilagus floridanus

jackrabbit

2

cottontail rabbit

2 ?

Neotoma microps

Lepisosteus spatula

packrat

alligator gar

1

1

unidentified turtle

Test 2

Level 1

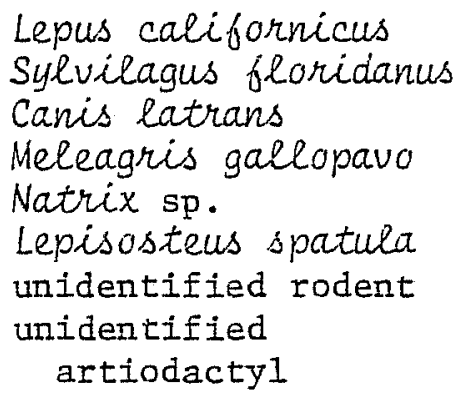

jackrabbit

cottontail rabbit

coyote

wild turkey

snake

alligator gar

1

2


TABLE 4.

Faunal Remains from Holdsworth II

Scientific Name

odocaileus virginiana Lepus califionicus Sylvilagus floridanus Canis latrans

Lunx rufus

Didelphis marsupialis

Sigmodon hispidus

Neotoma microps

Citellus mexicana.

Cratogeomys sp.

Peromyscus sp.

Perognathus sp.

Unidentified rodents

Pituophis melanoleucas

cratalus sp.

Elaphe sp.

Coluber sp.

Phrinosoma cornutum

Terrapene ornata

Pseudemys sp.

Unidentified frog

Hawk-size bird

Unidentified smali bird
Common Name

whitetail deer

jackrabbit

cottontail rabbit

coyote

bobcat

opossum

cotton rat

packrat

ground squirrel . 1

gopher

whytefooted mouse

pocket mouse

bullsnake

rattlesnake

rat snake

racer snake

horn toad

box turtle

slider turtle
No. Individuals

\section{4}

12

31

1

2

4

38

20

1

2

2

38

1

2

5

2

2

2

1

3

1

1 
TABLE 5 .

Faunal Remains from Test 4, $41 \mathrm{ZV} 14$ (1973)

Scientific Name

Odocoileus virginiana Lepus californicus Syevilagus floridanus Sigmodon hispidus Neotoma microps Terrapene ornata

Pseudemys sp.

Pituophis melanoleucas
Common Name

whitetail deer jackrabbit cottontail rabbit cotton rat packrat box turtle slider turtle bullsnake
No. Individuals

1

2

2

3

3

1

1

1 
BIBLIOGRAPHY

Calhoun, C. A.

1966 A Sma11 Campsite near Kenedy, Texas. Newsletter of the Houston Archeological Society 18: 3-6.

Campbe11, T. N.

1958 Archeology of the Central and Southern Sections of the Texas Coast. Bulletin of the Texas Archeological Society 29: 145-175.

Chang, K. C.

1972 Settlement Patterns in Archaeology. Addison Wesley Module in Anthropology 24.

Clark, J. W., Jr.

1973 The Problem of the Land Snail Genus Rabdotus in Texas Archeological Sites. The Nautilus 87 (1): 24.

Cook, S. F.

1972 Prehistoric Demography. Addison Wesley Module in Anthropology 16.

Corbin, J. E.

1974 A Model for Cultural Succession for the Coastal Bend Area of Texas. Bulletin of the Texas Archeological Society 45: 29-54.

Covey, C. (Editor)

1961 Cabeza de Vaca's Adventures in the Unknown Interior of America. New York.

Gilbert, B. M.

1973 Mammalian Osteo-Archaeology: Nort'́n America. Columbia, Missouri.

Hester, T. R.

1969 The Floyd Morris and Ayala Site: Discussion and Comparison. Bulletin of the Texas Archeological Society 40: $\quad 157-166$.

1970 An Interim Statement on Archaeological Research at Chaparrosa Ranch, Texas. Report submitted to the State Archeologist's Office, Austin. 
1971a Hunters and Gatherers of the Rio Grande Plain and the Lower Coast of Texas. Paper presented at annual meeting, Texas Academy of Science, Nacogdoches.

1971b Archeological Investigations at the La Jita Site, Uvalde County, Texas. Bulletin of the Texas Archeological Society: 51-148.

1971c Marine Shells from Archeological Sites in Southwestern Texas. Texas Journal of Science 22: 87-88.

1972a Toltec Artifacts from Southern Texas. Southwest Museum Masterkey 46: 137-140.

1972b The Evidence for Prehistoric Trade on the Rio Grande Plain. Archaeological Papers Presented to J. W. House: 21-25. Berkeley.

1972c The Surface Archeology of Three Sites in Duval County, Southern Texas. Bulletin, Lower Plains Archeological Society 2 (for 1971): 45-71.

1974 a Prehistoric Subsistence and Settlement Systems on the Rio Grande Plain, Southern Texas. Yearbook of the American Philosophical Society 1973: 594-596.

1974b Some Observations on Archaeology at Chaparrosa Ranch, 1974. La Tierra 1 (3): 19-22.

1975 Chipped Stone Industries on the Rio Grande Plain, Texas: Some Preliminary observations. Texas Journal of Science $26(1-2)$ : 213-222.

1977 Archaeological Research at the Hinojosa Site (4I JW 8), Jin Wells County, Southern Texas. The University of Texas at San Antonio, Center for Archaeological Research, Archaeological Survey Report 4.

Hester, T. R. and T. C. Hill, Jr.

1969 Mogollon Ceramics from Southern Texas. The Artifact 7 (3): 11-15.

1971 An Initial Study of a Prehistoric Ceramic Tradition in Southern Texas. Plains Anthropologist 16: 195-203.

1973 Prehistoric Occupation at the Holdsworth and Steward Sites on the Rio Grande Plain of Texas. Bulletin of the Texas Archeological Society 43: 33-65.

1975 Eating Iand Snails in Prehistoric South Texas. The Nautilus 89 (2): $37-38$. 
Hester, T. R., T. C. Hill, Jr., D. Gifford, and S. Holbrook

1975 Archaeological Salvage of Site 41 ZV 152, Rio Grande Plain of Texas. Texas Journal of Science 26 (1-2): 223-228.

Hester, T. R., J. W. House, R. N. Jack, and F. H. Stross

1975 X-Ray Fluorescence Analysis of Archaeological Obsidian from the Rio Grande Plain of Texas. Texas Journal of Science $26(1-2)$ : 286-289.

Hester, T. R. and R. C. Parker

1970 The Berclair Site: A Late Prehistoric Component in Goliad County, Southern Texas. Bulletin of the Texas Archeological Society 41: 1-24.

Hester, T. R. and H. J. Shafer

1975 A Study of Blade Technology on the Central and Southern. Texas Coast. Plains Anthropologist (in press).

Hester, T. R., L. D. White, and J. White

1969 Archeological Materials from the Oulline Site and Other Sites in LaSalle County, Texas. Texas Journal of Science 21: 130-165.

Hill, T. C., Jr.

1975 Experiments in Pottery Making. La Tierra 2 (3): 4-30. Hi11, T. C., Ir. and T. R. Hester

1971 Isolated Late Prehistoric and Archaic Components at the Honeymoon Site (41 ZV 34), Southern Texas. Plains Anthropologist 15: 52-59.

1973 A Preliminary Report on the Tortuga Flat Site: A Protohistoric Campsite in Southern Texas. Texas Archeology 17 (2): 10-14.

Hi1l, T. C., Jr. and M. Holdsworth

1973 Paper presented at annual meeting, Texas Archeological Society, Lubbock.

Hill, T. C., JI., J.W. House, and T. R. Hester

1972 Notes on. Incised and Grooved Stones from Southern and Western Texas. Bulletin, Lower Plains Archaeological Society 3: 1-10. 
Hold sworth, J.

1973 A Study of Modern Flora and Fauna in the Vicinity of the Holdsworth Site (41 ZV 14). Appendix I, In: Prehistoric Occupation of the Holdsworth and Stewart Sites on the Rio Grande Flain of Texas. Bulletin of the Texas Archeological Society 43: 65-73.

Inglis, J. M.

1964 A History of Vegetation on the Rio Grande Plain of Texas. Texas Parks and Wildlife Bulletin 45.

Kelley, J. C.

1948 Arrow or Dart Shaft Tools and Problematical Incised Stones from Central and Western Texas. El Palacio 55 (3): $63-85$.

Krieger, A. D.

1956 Food Habits of the Texas Coastal Indians in the Early Sixteenth Century. Bulletin of the Texas Archeological Society $7: \quad 47-58$.

Kroeber, A. D.

1925 Handbook of the Indians of California. Bureau of American Ethnology Bulletin 78.

MacNeish, R. S.

1958 Preliminary Archaeological Investigations in the Sierra de Tamaulipas, Mexico. Transactions, American Philosophical Society 48 (6).

Naroll, R.

1962 Floor Area and Settlement Pattern. American Antiquity 27: $587-589$.

Newcomb, W. W., Jr.

1961 The Indians of Texas. University of Texas Press, Austin. Nunley, J. P.

1971 Archaeological Interpretation and the Particularistic Model: the Coahuiltecan Case. Plains Anthropologist 16 (54): $302-310$.

Nunley, J. P. and T. R. Hester

1966 Preliminary Archeological Investigations in Dimmit County, Texas. Texas Journal of Science 18 (3): 233-253. 
Prewitt, E. R.

1974 Preliminary Archeological Investigations in the Rio Grande Delta of Texas. Bulletin of the Texas Archeological Society 45: 55-66.

Price, W. A. and G. Gunter

1943 Certain Recent Geological and Biological Changes in South Texas, With Consideration of Probable Causes. Proceedings and Transactions, Texas Academy of Science 26: $138-156$.

Ralph, E. K., H. N. Michael, and M. C. Han

1971 Radiocarbon Dates and Reaiity. MASCA Newseteter 9 (1): $1-19$.

Reeves, H. C.

1973 Fire in the Management of Vegetation. Journal of Geography 72 (2): $31-37$.

Ruecking, F, Jr.

1953 The Economic System of the Coahuiltecan Indians of Southern Texas and Northeastern Mexico. Texas Jounnal of Science 5: 480-497.

1955 The Coahuiltecan Indians of Southern Texas and Northeastern Mexico. M.A. Thesis, University of Texas at Austin.

Shafer, H. J.

1971 Late Prehistory of Central Texas. Paper presented at amnual meeting, Texas Academy of Science, Nacogdoches.

Suhm, D. A.

1957 Excavations at the Smith Rockshelter, Travis County, Texas. Texas Journal of Science 9 (1): 26-58.

1958 A Review of Central Texas Archeology. Bulletin of the Texas Archeological Society 29: 63-107.

Suhm, D. A., A. D. Krieger and E. B. Jelks

1954 An Introductory Handbook of Texas Archeology. Bulletin of the Texas Archeological Society 24. 
Walker, E. F.

1933 Desert Arrows with Wooden Points. Southwest Museum Masterkey 7 (4): 105-110.

Weddle, R. S.

1968 San Juan Bautista. Gateway to Spanish Texas. University of Texas Press, Austin.

Weir, F. A.

1956 Surface Artifacts from La Perdida, Starr County, Texas. Bulletin of the Texas Archeological Society 26: 59-78. 